\title{
Dividend Announcements and Market Trends
}

\author{
Nagendra Marisetty ${ }^{1} \&$ M. Suresh Babu ${ }^{2}$ \\ ${ }^{1}$ Reva Business School, Reva University, Bangalore, India \\ ${ }^{2}$ Retired Professor, Sri Venkateshwara University, Tirupati, Andhra Pradesh, India \\ Correspondence: Nagendra Marisetty, Faculty, Reva Business School, Reva University, Bangalore, Karnataka, \\ India. E-mail: nagendra.marisetty@gmail.com
}

Received: August 21, 2021

Accepted: September 11, 2021

Online Published: September 15, 2021

doi:10.5539/ijef.v13n10p139

URL: https://doi.org/10.5539/ijef.v13n10p139

\begin{abstract}
This research primarily aims to study the impact of dividend announcements on the stock price of companies listed in the Indian stock market. Incidental to the study, it is necessary to understand whether the market trends have any role in affecting the changes in share prices due to dividend announcements. The companies listed on the stock market are diverse in terms of the industry, market capitalization, and performance. We analyze the S\&P BSE 500 index stocks, which declare cash dividend every year without fail for ten years from $2008-17$. Total 1755 sample was tested for dividend announcement and sample divided into large, medium, and small sample sizes based on the market capitalization of the stocks to test the market trend effect. Event methodology market model used to calculate the abnormal returns on the dividend announcement day.

The present research study examined the impact of dividend announcements on stocks in the Indian stock market. The results observe in twenty-four times based on market capitalization wise and market trend-wise dividend announcements. The results of the study are not the same for all dividend announcement observations. The study found positive abnormal returns on event day in most of the dividend announcement observations and it is similar to Litzenberger and Ramaswamy (1982), Asquith and Mullins Jr (1983), Grinblatt, Masulis, and Titman (1984), Chen, Nieh, Da Chen, and Tang (2009) and many previous research results studied in major developed stock markets and emerging stock markets. Full sample, large-cap, and small-cap final dividend average abnormal returns are positively significant only in bull market trend (period 2) similar to Below and Johnson (1996) and other market trends final dividend announcement abnormal returns are positive in most of the observations, but returns are not significant. Average abnormal returns are sensitive to market trends, especially abnormal small-cap returns more vulnerable to market trends.
\end{abstract}

Keywords: dividend announcements, market trends, bull market, bear market, Indian stock market

\section{Introduction}

In the period 2008-2017, in the very first week by January 2008, the Indian stock markets were on massive bullish trends especially on the 10th day when the benchmark index BSE SENSEX was recorded at 21,206.77 points, supported by domestic institutional investors and retail investors on expectations that India will remain one of the most reliable destinations to foreign institutional and domestic investors. By 21st January 2008, the market sentiment dramatically changed and the benchmark index BSE SENSEX experienced the most significant single day loss ever due to possible global financial crisis and that bear sentiment continued another one year till the markets recovered. In the year 2011 also, the markets started losing the value and this continued till the beginning of 2012 when the markets finally recovered and another bearish trend observed during the period 2015 -2016 also. During 2008 - 2017, Indian stock markets market capitalization increased from Rs. 50 lakh crores in 2008 to Rs. 150 lakh crores in 2018 almost a 3x time's growth in ten years.

Many factors, like the country's financial situation, currency fluctuation, crude oil fluctuation, trade wars, development of a country, etc., influence the world economic growth. The world economic growth affects the country's growth also because the economy now is a global factor. Growth of country's influence by along with the world economy and local factors also like political stability, currency stability, industry growth, financial institutions growth, investments, savings, stock market growth, corporate growth, and many more. Rise in the stock markets is influenced by domestic economic factors as well as global factors. An important thing to note is how stock markets influence corporate announcements and vice versa. 
An abnormal return narrates the unusual gains produced by specific stock or group of stocks over a period of time or a particular day. Abnormal returns may be positive or negative, finds risk-adjusted returns. Below and Johnson (1996), Ngoc and Cuong (2016), and Chavali and Nusratnnisa (2013) observed positive abnormal returns around dividend announcements, but Gunalp, Kadioglu, and Kilic (2011), noted a significantly negative relationship between dividend announcement and stock price. Signaling is a theory that tells how the firm announcement of dividend announcement is a sign of positive or negative future earnings. This is the most researched area after abnormal returns. Gupta, Dogra, Vashisht, and Ghai (2012), Dasilis (2007), and Elfakahani (1998) proved dividend announcements provide signals to the market.

Chen, Nieh, Da Chen, and Tang (2009), and Vieira and Rapos (2007) observed weak evidence for the signalling hypothesis. In semi-strong form of efficiency, the security prices reflect all publicly available information. This implies that an investor will not be able to outperform the market by analyzing the current company-related or other relevant information. Corporate announcements use one of the new information to measure the efficiency of the stock markets. Fama, Fisher, Jensen, and Roll (1969), Chavali and Zahid (2011), Hua and Ramesh (2013), supported the efficient market hypothesis; which means that the market quickly adjusts to corporate announcements information. Although Gupta, Dogra, Vashisht, and Ghai (2012), Dasilis (2007) do not support the efficient market hypothesis.

\section{Review of Literature}

Kalay (1982) examined the ex-dividend day behaviour of stock prices by using the 2540 observations during 1962-1965 in USA markets. The author found a positive relationship between the price drop on ex-dividend date behaviour and corresponding dividend yield. The author concluded that share prices behaviour on ex-dividend day is not influenced by either tax effect or clientele effect. Litzenberger and Ramaswamy (1982) examined the cause of dividend effects on equity share prices is tax effect or information effect by using New York Stock Exchange stocks (NYSE), USA, during the period from 1940 to 1980. They found how equity share price returns and future dividend yields have a positive and non-linear relationship. The forecast rule for future dividends is purely on information that is accessible to the investor ex-ante. They concluded that significant dividend yield effects on equity share price returns could not be attached to the information content in the previous awareness that the company will announce a dividend of unknown immensity.

Asquith and Mullins Jr (1983) studied the dividend payment initiation impact on the wealth of shareholders in the USA stock market by observing 168 companies first dividend or initiation of the dividend during the period 1954-1963. They found more returns from dividend firms than any previous studies on dividends. The returns are positively associated with the size of the initial dividend payment. Their results support the subsequent increase of dividend may result in a more positive impact on the wealth of shareholders than the dividend initiation. They concluded that dividends convey distinctive and worthy information to investors from the results of first-time dividend and dividend initiation. John and Lang (1991) investigated insider trading around corporate dividend announcements in USA markets during 1975-1985. Their study based on the efficient equilibrium in a signalling model with endogenous insider trading. They found that abnormal returns are negative and significantly less for companies with insider selling before the dividend initiation announcement than the without insider trading companies or only insider buying companies. Authors concluded that insider trading is a signalling thing, combining with corporate dividend signals, it may be a helpful outlook to understand insider trading around dividend announcements and related price effects.

Below and Johnson (1996) investigated dividend increase, decrease announcements and information content hypothesis (ICH) on the stock market price changes in different market phases. Their sample consists of 2434 dividend increase announcements and 323 dividend decrease announcements of companies listing in NYSE / AMEX during the period from 1970 to 1982. Authors divided the market trends into four periods, two bull markets and two bear markets, depending on the index movement. They found significant abnormal returns around dividend announcements in market trends. Dividend increase (good information) and dividend decrease (bad information) announcements have a significant impact on the market price of share in different market trends. Elfakahani (1998) examined the dividend signals expected favourableness, dividend change direction and dividend announcement signalling role. The sample contains 427 dividend announcements, 334 increases, and 93 decreases, during the period from 1976-1985. He proposed the dividend signal has three parts, first is dividend signal expected favourableness (good, bad or ambiguous), second is dividend change direction (positive or negative) and last is dividend signal role (confirmatory, clarificatory or unclear). The author found that dividend increase / decrease / no change announcements affect the market price of the stocks and also saw that the signalling role of dividend announcement has a considerable impact on the company's market price. The study concluded that in all three signalling factors, dividend signal expected favourableness becomes the 
influential factor.

Bessler and Nohel (1999) investigated the asymmetric information, dividend reductions and contagion effects in bank stock returns by using 17 banks' regular dividends during the period 1975 to 1981 . They used event methodology to calculate the abnormal returns and cumulative abnormal returns surrounding dividend announcement days. They tested the contagion effect presence in share returns associated with dividend announcements of money centre banks. They found that dividend decreases instigate the negative abnormal returns in the shares of non-announcing money centre banks. They concluded that contagion impacts appear consistent with informed rather than the contagious panic behaviour. Fama and French (2000) studied the disappearing dividends: changing firm characteristics or lower propensity to pay? They examined the company's listing in NYSE, AMEX, and NASDAQ during the period from 1963 to 1998 in US capital markets. In their analysis, they found that cash dividend-paying companies drastically reduced to $20.8 \%$ in 1999 from $66.5 \%$ in 1978 and also find that downfall because of changing features of public traded companies. The authors concluded that publicly listed companies moving profoundly towards small companies with less profitability and powerful growth opportunities.

Bandara and Samarakoon (2002) studied the Sri Lanka stock market to investigate the dividend announcement information content impact, dividend announcements by firm size effect, and dividend growth impact on stock prices. The sample contains 37 companies listing in Colombo stock exchange and study period from 1993 to 1998. They found significant dividend information impact on stock prices in the Sri Lanka equity market and also it is a positive impact in the market on an average. Small companies reacted strongly to dividend announcement information content and better dividend growth announcements. They also found that something different impact on stocks when companies were announcing lower dividend growth. Finally, concluded that the Sri Lankan stock market is an informationally efficient market to its inconsistent results. Brio (2004) studied the Spanish stock market to know the link between dividend payments and insider trading. The sample consists of 624 dividend announcements, 319 dividend increases, 219 dividend decreases, \& 82 no change announcements, from 83 non-financial companies listing in the Spanish market (SIBE) during the period from 1992-1996. He found that the Spanish stock market responds positively (negatively) to hike in dividends when dividend payments are fallow of insiders buy (sell). The author concluded that for the Spanish stock market, it is too simple guessing that increase in dividends announcement is always regarded as excellent news by the market.

Amihud and Li (2005) studied the impact of institutional holdings on dividend announcements and dividend announcement declining information content in the American stock market. Authors used the event methodology to explain the "disappearing dividend" phenomenon, and the sample size is 16, 189 quarterly announced dividend events collect from American companies from 1962-2000. They proposed the two hypotheses in their study. One is the "disappearing dividend" phenomenon, and the second one is the institutional holding hypothesis. They found that market price reannouncement is a decreasing trend to dividend increase/decrease announcements in the late 70s and also finds that in high institutional holding firm stocks market price response to dividend announcement is less. Companies with a more institutional stake are less likely to increase their dividends. They concluded that disappearance dividends indicate the decreasing job of dividends as a means to convey information due to the institutional stake hike in companies.

Dasilas (2007) examined the stock market reannouncement to dividend announcements in the Greek stock market. The author used the 216 dividend announcements from the period of 2000 to 2004 to check the market price of the stock and volume reannouncement to dividend change announcements. The dividend announcement day stocks abnormal returns are minimum at 0.324 percent and abnormal returns are above $1 \%$ for dividend increase announcements. The study concluded that the market price of the shares reacts significantly to dividend increase/decrease announcements and also supports the "information content of dividend hypothesis." Vieira and Raposo (2007) examined the European stock markets to understand the dividend increase or decrease announcement impact on market price returns. They investigated the classical beliefs of the dividend signalling hypothesis by using the data from three European countries, United Kingdom, France, and Portuguese. Their sample consists of 2662 dividend increases, 273 decreases \& 343 no change announcements from the UK, 235 increases, 62 decreases \& 59 no change dividend announcements from France during the period 1995-2002 and 158 increases, 121 decreases \& 101 no change dividend announcements from Portuguese market during the period 1989-2002. Their results do not carry the positive connection between the dividend increase/decrease announcements and the stock price changes for French companies. For Portuguese and UK companies, it is a weak positive connection between the dividend increase/decrease announcements and the stock price changes.

Blau, Fuller, and Ness (2009) investigated the short-selling surround announcement of dividend date and ex-dividend dates by using 777 New York Stock Exchange (NYSE) listed companies. They used the quarterly 
dividend announcement data and data period belongs to 2005 and 2006. Before the dividend announcement increases (decreases), they did not find any irregular less (more) short-selling. But, they found that before the adverse announcement of dividends short-selling task is less lucrative than short-selling task surround non-event time. They also found that after the ex-dividend day, short-selling activity is a high return activity. Finally, the authors concluded that for the short-sellers announcement of dividends does not give any lucrative trading chances. Chen, Nieh, Da Chen, and Tang (2009) investigated the A-share companies in the China equity market from 2000 to 2004 by using the event methodology to determine the impact of cash dividend changes and also to investigate the Chinese share markets holds the signalling hypothesis or not. The sample contains 460 companies with cash dividend increase announcements and 422 companies with cash dividend decrease announcements from Shanghai stock exchange and Shenzhen stock exchange. They found that the Chinese stock market reacted positively to cash dividend changes announcement, but partially support the signalling hypothesis of dividends.

Gunalp, Kadioglu, and Kilic (2011) examined the impact of cash dividend announcement on the market price of the share in Turkish capital markets. They analyzed the abnormal returns that surround the dividend announcement date by using event study methodology. Authors pick the 429 cash dividend announcement events from 80 firms from 2003 to 2009. They find that abnormal returns after the announcement and cash dividends per share have a significant negative connection and also their research evidence holds the tax clientele effect hypothesis. The inefficiency of the Turkish capital markets reduced over time and according to their study, share price adjustment begins at event day only, whereas the remarkable price adjustment happens between event day and second day after the event. Hussainey, MGBAME, and MGBAME (2011) investigate the connection between stock price changes and dividend policy in the United Kingdom stock market. Multiple regression model and ten years of data from 1998 to 2007 used to test the relationship between dividend policy and stock price reannouncement. They found that stock price reannouncement is positive to dividend yield and stock price reannouncement is contrary to dividend pay-out ratio. The more dividend pay-out means minimal variability, a share price would be at and the dividend pay-out ratio is an essential cause of variability of the share price. They also found that the company's growth rate, debt level, size, and earnings cause the share price changes.

Gupta, Dogra, Vashisht, and Ghai (2012) investigated the stock price reannouncement to dividend announcement in the Indian stock market. They choose the sample of 65 dividend announcements that happen from 2006 to 2009 from 28 firms listed in BSE SENSEX. Event methodology used to know abnormality of stock price returns around dividend announcements. They found that share prices respond positively to dividend increase announcements and also found that announcement of dividend holds the signalling hypotheses. They concluded from their study that, Indian stock market is not efficient. Chavali and Nusratunnisa (2013) studied the Indian stock market to find the announcement of dividend impact on the stock price returns. They picked the 67 dividend announcements from the fast-moving consumer goods industry (FMCG), which happens during the 2007 to 2011 period. Authors used the event methodology to calculate stock's abnormal returns around dividend announcement dates and also use the 41 days event window. They found that stock price abnormal returns are positive and results are statistically significant around dividend announcement days.

Berdnikova and Rogova (2014) examined the Russian firms' market price reannouncement towards the announcement of dividends. They analyzed the market price reannouncement towards dividend announcements in different sectors. The sample consists of 115 dividend announcements from Russian public firms and sample announcements occur from 2009 to 2013. The event methodology model is used to calculate the abnormal return movements around dividend announcement dates. They found that market price reacts opposite to dividend change announcements like if dividend change announcements are good, share price and market capitalizations response opposite to this news and if dividend change announcement is bad, market price and market value of the share react positively to this news. Ngoc and Cuong (2016) examined the dividend announcements date and ex-dividend announcement date effect on share price returns in the Vietnam stock market. Their sample size is 1962 events from 432 companies listed in the Vietnam stock market and research period from 2008 to 2015. They used the event study methodology to calculate the abnormal returns around the dividend announcement date and ex-dividend announcement date. They found positive abnormal returns surrounding the dividend announcement date and also observed an upward movement trend in share price till ex-dividend date approaches and then a downward trend from ex-dividend date.

It can be understood from above review of literature that some researchers proved that cash dividend announcements impact on stock prices and some researchers not found any evidence for stock price rection to cash dividend announcements. Another thing is that most of the researchers not studied the dividend announcements impact on stock price in different market trends. 


\section{Research Methodology}

\subsection{Objectives of the Study}

From the above discussion, the study is undertaken with the following objectives.

- To examine whether the impact of dividend announcements on stock prices varies with a market capitalization of the company or not?

- To analyze whether the impact of dividend announcements on stock prices varies with trends of the stock market or not?

\subsection{Research Hypotheses}

The following hypotheses are posited to test while researching this study. They are grouped under the following heads.

- $\quad \mathrm{H}_{0}$ : There is no significant impact of dividend announcements by market capitalization wise on the stocks in India

- $\quad \mathrm{H}_{2}$ : There is no significant impact of dividend announcements during different market trends by market capitalization wise on the stocks in India

\subsection{Data Collection}

The period for this study is from 2008-17, which is the period witnessed significant fluctuations in the Indian stock market. During this period, stocks went from high level to low level and low level to high level two to three times. Many stock exchanges are operating in India, but only two, namely the Bombay Stock Exchange (BSE) and National Stock Exchange, are the major exchanges that operate at the national level. BSE is one of the oldest stock exchange and more number of companies are listed exchange in India. BSE has been selected for the representation of the Indian Stock Market for the selection of dividend announcements and identification of the companies. Stock price information collected from BSE website, dividend announcement information collets from moneycontrol.com, capitalmarkets.com, and data cross-check with BSE website.

\subsection{Sampling Procedure \& Sample Selection}

Non-probability sampling technique (judgement sampling) used for the selection of the companies for this study. Sample events selected form S\&P BSE 500 companies only because S\&P BSE 500 is a broader index and index constitutes $90 \%$ above the capitalization of the total market capitalization. BSE Large-cap, BSE Mid-cap, and BSE small-cap indexes used to segregate the sample into market capitalization wise. BSE stock exchange regularly reconstitutes the indexes based on market capitalization wise of the companies, so it makes it challenging to select the sample for the study. Hence market capitalization base has taken companies which are there in January 2018 BSE indexes list only.

\subsection{Dividend Announcements Selection}

Two assumptions assumed for the selected samples for dividend announcement. First, the minimum investor preference of dividend is 10 percent. The second one is that the announcement of dividend is compulsory every year because it gives to measure the dividend impact in different market trends from the same company samples.

1) In the first step, total dividend announcements considered which announced during the research period.

2) The second step in a year if any company announced dividends more than one time, then taken only one dividend (preference given final dividend if not highest percentage interim dividend picked) and excluded other dividend announcements for study.

3) In the third step, samples only included $10 \%$ and above dividend announcements.

4) In step four, identification of companies that have paid dividends regularly every year throughout the research period.

5) In step five, only S\&P BSE 500 index companies selected form step four companies.

6) In steps 6, 7, and 8 large-cap, mid-cap, and small-cap companies selected from S \& P BSE 500 companies chosen from step five.

7) Selection of samples for dividend announcements shows in the following tables 。 
Table 1. Summarizes the step wise selection of dividend announcements

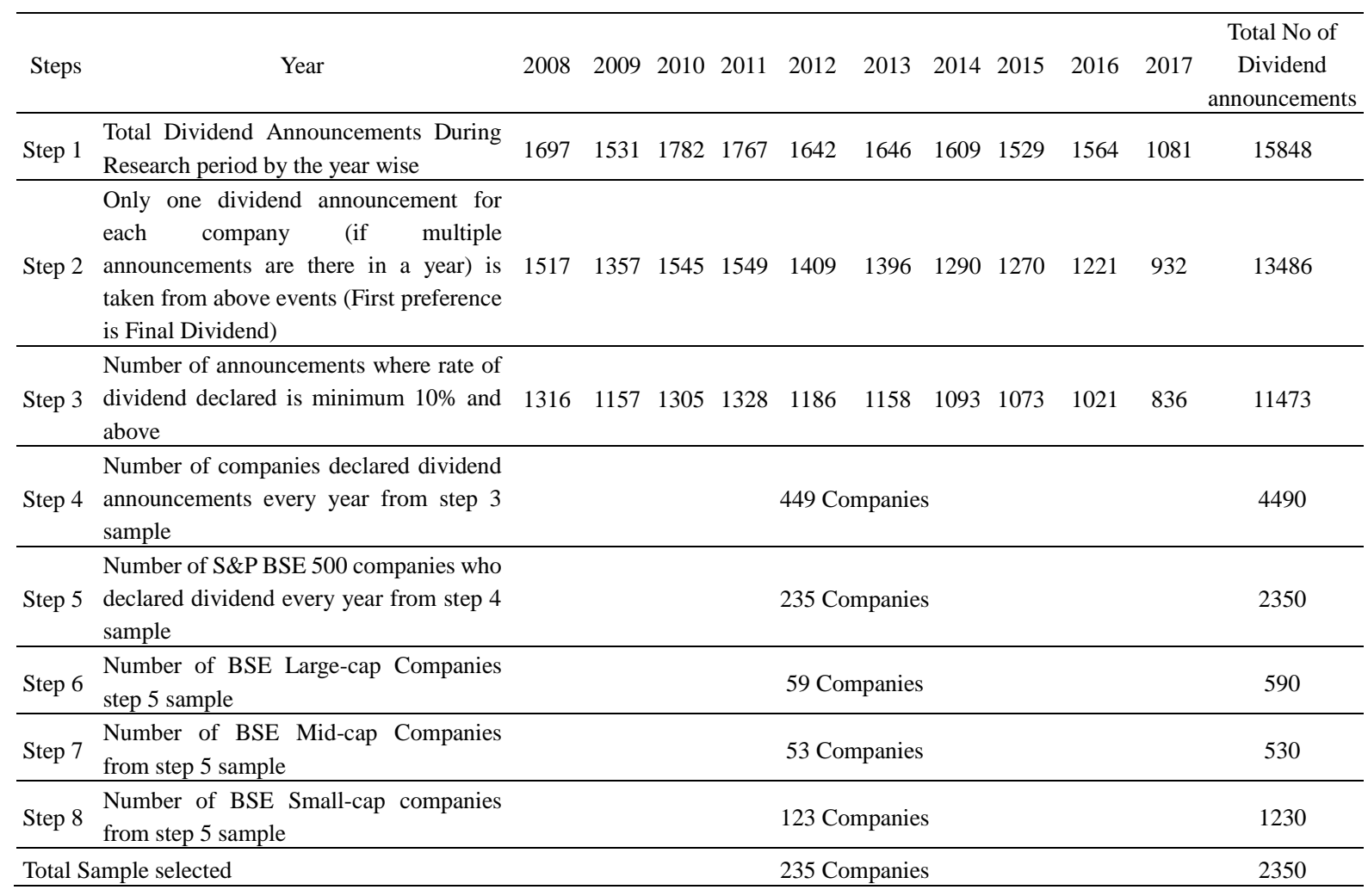

Source: bseindia.com and moneycontrol.com

Table 2. Break-up of the different dividend announcements based on different market capitalization wise

\begin{tabular}{lcccccccc}
\hline $\begin{array}{l}\text { Type of } \\
\text { Capitalization }\end{array}$ & $\begin{array}{c}\text { Final } \\
\text { Dividend }\end{array}$ & $\begin{array}{c}\text { Interim } \\
\text { Dividend }\end{array}$ & $\begin{array}{c}\text { Dividend with } \\
\text { Bonus }\end{array}$ & $\begin{array}{c}\text { Dividend } \\
\text { with Split }\end{array}$ & $\begin{array}{c}\text { Dividend with } \\
\text { Bonus \& Split }\end{array}$ & $\begin{array}{c}\text { Clash with } \\
\text { Others events }\end{array}$ & $\begin{array}{c}\text { Price info } \\
\text { missing* }\end{array}$ & $\begin{array}{c}\text { Total } \\
\text { Large }\end{array}$ \\
Mid-cap & 492 & 35 & 20 & 8 & 2 & 3 & 30 & 590 \\
Small & 425 & 42 & 12 & 6 & 1 & 4 & 40 & 530 \\
Total & 838 & 66 & 6 & 12 & 1 & 17 & 290 & 1230 \\
\hline
\end{tabular}

Note. * 3 large, 4 mid-cap and 29 small companies are not traded some days during research a period,

Source: Author's Calculations 。

For this research 1755 final dividend announcements were selected to test the market trend hypothesis

Final dividend announcement during different market trends (Trend Hypothesis)

S\&P BSE 500 Index points from 2008 to 2017 collected from bseindex.com and plotted in the following chart.

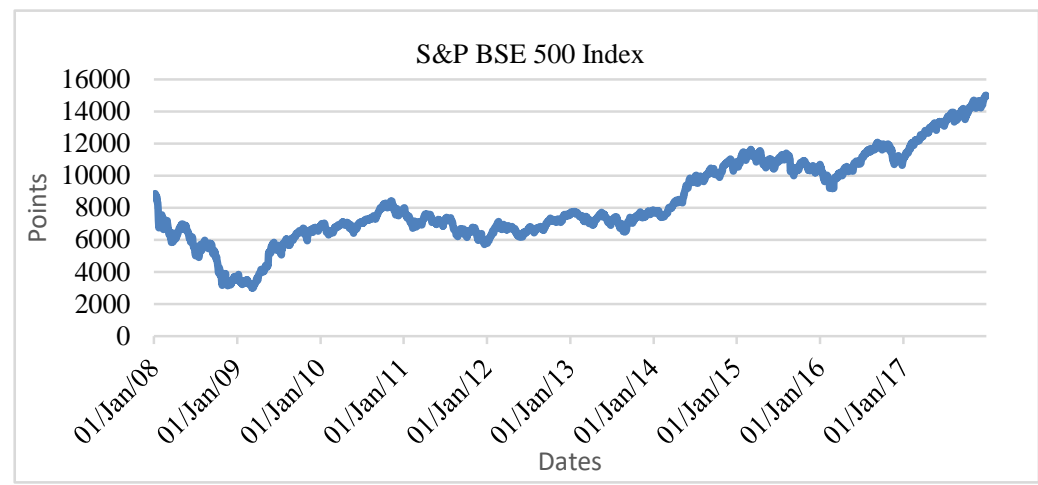

Figure 1. S\&P BSE 500 Index from 2008 to 2017

Source: S\&P BSE 500 Index Day closing prices. 
Figure 1 shows the up and downs of S\&P BSE 500 Index. Initially, the index shows the downward trend and the trend continues for almost more than one year. After that, the chart shows an upward trend in the index and it is nearly two years then the index shows a downward trend for another year. After that, it can observe from the chart that a continuous upward trend for another three years then indexes went down for one year. Finally, the chart shows an upward trend in the index and it is almost more than two years. The popular definition of bull or bear market from Investopedia and other websites is a 20 percent increase or decrease of indexes or stocks from low or high called bull or bear market, respectively. From that definition, the S\&P BSE 500 index segregated three bull and three bear markets in the study period from 2008 to 2017 as follows.

Table 3. Market trends classification of S\&P BSE 500 index during the period of 2008 to 2017

\begin{tabular}{cccccc}
\hline P. No & Market Trend & Period & Points change & \% Change & Duration in months \\
\hline Period 1 (P 1) & Bear & 3, Jan'2008 to 3, March 2009 & 8746.04 to 3081.73 & $-64.76 \%$ & 14 \\
Period 2 (P 2) & Bull & 4, March 2009 to 5, November 2010 & 3081.79 to 8405 & $172.73 \%$ & 20 \\
Period 3 (P 3) & Bear & 6, Nov 2010 to 16, Dec 2011 & 8405 to 5855.86 & $-30.32 \%$ & 14 \\
Period 4 (P 4) & Bull & 17, Dec 2011 to 5, March 2015 & 5855.86 to 11567.69 & $97.54 \%$ & 38 \\
Period 5 (P 5) & Bear & 6, March 2015 to 12, Feb 2016 & 11567.69 to 9215.17 & $-20.34 \%$ & 11 \\
Period 6 (P6) & Bull & 13, Feb 2016 to 01, Jan 2018: & 9215.17 to 14,951.08 & $62.24 \%$ & 23 \\
\hline
\end{tabular}

Source: closing prices from www.bseindia.com.

It can be observed from Table 3 that bull trend is there maximum months than bear trend during the research period. The maximum gain of index found in period 2, and this trend was there twenty months. The maximum loss of index observes in period 1 and this trend was there for more than one year. The minimum gain of index observes in period 6 and this trend was there for almost two years. Minimum loss of index observes in period 5, and this trend was there around one year. The maximum duration of trend is period 4 (bull), it is almost more than three years and the minimum duration of trend is period 5 (bear); it is around one year.

Based on the above different periods, final dividend announcements by market capitalization wise segregated in the following Table 4.

Table 4. Final dividend announcements by market capitalization wise in different market trends (periods)

\begin{tabular}{lccccc}
\hline Period & Market trend & Large-cap & Mid-cap & Small-cap & Total \\
\hline Period 1 & Bear & 54 & 50 & 101 & 205 \\
Period 2 & Bull & 97 & 79 & 144 & 320 \\
Period 3 & Bear & 51 & 47 & 89 & 187 \\
Period 4 & Bull & 154 & 131 & 274 & 559 \\
Period 5 & Bear & 55 & 45 & 86 & 186 \\
Period 6 & Bull & 81 & 73 & 838 & 298 \\
\hline Total & & 492 & 425 & 144 & 1755 \\
\hline
\end{tabular}

Source: Author's calculations.

\subsection{Event Window Selection}

India being a developing country with an evolving capital market, it is characterized by volatility in short period. The transparency of the dividend world is questionable and there appears to be large scale insider trading before the announcement of any event. Therefore, the researcher has chosen 61 days as the event window for the study on the impact of dividend announcements on the stock market. This 61-day event window, which is defined 0-days (the date on which event is publicly announced) and -30 to +30 days (the date 30 days previous from the event date and 30 days post event dates) for the study. The efficiency of the market analyses by using CAAR (Cumulative Average Abnormal Returns) in different window periods, such as 61 days, 41 days, 21 days, 11 days, 5 days, and 3 days. This study is associated with the stock price behaviour surrounding the announcement date and therefore labelled as an event study. The methodology of an event study is associated with the Efficient Market Hypothesis developed by E. F. Fama (1970), to understand the adjustment of stock prices to new information. The methodology is commonly referred to as Fama Fisher Jensen and Ross (1969) methodology of an event study.

The steps followed to study the events are as follows; 
Step 1: Identify the events to be studied and pinpoint the date $(\mathrm{t}=0)$ on which the events are announced.

Step 2: Decide on the event window (ensure that during this period, no other important event has been announced). The event window dividend announcement as $\mathrm{t}=0$ (Event date) and a period of -30 days previous to the event date and +30 days after the event date, which is shown below with the help of the graph.

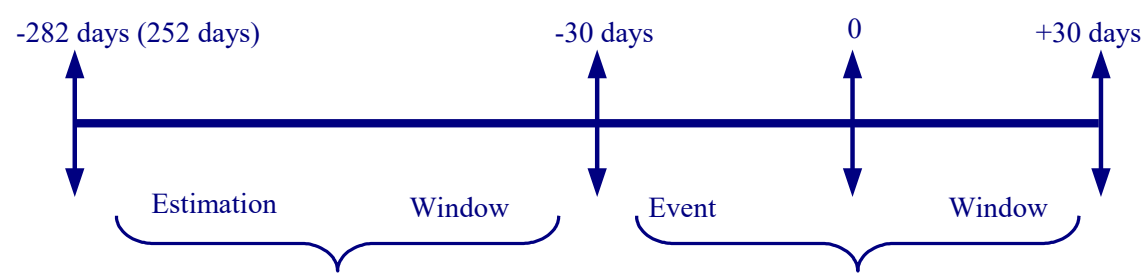

In this figure, $\mathrm{t}=0$ is shown as event announcement date and the respective effect of this announcement on share prices is calculated for the period of -30 days to +30 days to know if there is any impact of such announcement and for how many days it persists. The estimation window will be -282 days to -30 days of the event day window to regress the stock and index.

\subsection{Tools Used for the Study}

ADF test to know the stationery of time series data, Market model for event study, Alpha coefficient, Beta coefficient, Descriptive statistics - Max, Min, Mean, Median and Standard deviation, Abnormal returns, Average abnormal returns, Cumulative average abnormal returns and Paired $\mathrm{t}$ test

\section{Market Model as fallows}

Expected Return (E) $=\alpha+\beta R_{M}$

$\alpha=$ Alpha coefficient of security with the Index; $\beta=$ Beta coefficient of the security with the Index

$\mathrm{R}_{\mathrm{M}}=$ Expected of the return of the Index

Abnormal returns calculated as fallows

$$
\mathrm{AR}=\mathrm{R}-\mathrm{E}
$$

$$
\mathrm{R}=\text { Actual Returns; } \mathrm{AR}=\text { Abnormal returns; } \mathrm{E}=\text { Expected returns }
$$

Average Abnormal returns calculated as fallows

$$
\mathrm{AAR}=\frac{\sum_{t=1}^{n} A t}{n}, \mathrm{t}=\text { the number of securities in the study; } \mathrm{n}=\text { total number of stocks in the class }
$$

$t$ test used to determine the significance of abnormal returns

$$
t=\frac{A A R}{\sigma(A A R)}
$$

$$
A A R=\text { Average abnormal return; } \sigma(A A R)=\text { Standard error of average abnormal return; }
$$

Standard error is calculated is $(\mathrm{AA} R)=\frac{\sigma}{\sqrt{n}}$

\section{Data Analysis and Interpretation}

4.1 Bear Market Trend (Period 1: $3^{\text {rd }}$ Jan 08 to $3^{\text {rd }}$ Mar 09)

Table 5. Abnormal returns descriptive statistics of final dividend announcements by market capitalization during bear trend (Period 1) on event day

\begin{tabular}{clcccccc}
\hline \multirow{2}{*}{ S. No } & \multirow{2}{*}{ Sample details } & $\mathrm{N}$ & \multicolumn{5}{c}{ Descriptive statistics of abnormal returns (\%) } \\
\cline { 4 - 8 } & & & Max & Min & Mean & Median & SD \\
\hline 4.1 .1 & Full sample & 205 & 18.664 & -8.766 & 0.188 & -0.222 & 3.652 \\
4.1 .2 & Large-cap & 54 & 6.321 & -7.736 & -0.227 & -0.505 & 2.598 \\
4.1 .3 & Mid-cap & 50 & 14.707 & -6.795 & 0.343 & -0.079 & 3.487 \\
4.1 .4 & Small-cap & 101 & 18.664 & -8.766 & 0.333 & -0.204 & 4.188 \\
\hline
\end{tabular}

Note. Author's calculations by using stock prices from bseindia.com.

Above Table 5 says that small-cap final dividend announcement during bear trend (period 1) sample size is high compare to other observations. Its maximum abnormal return is positive and highest compared to mid-cap and large-cap maximum abnormal return on event day. Large-cap abnormal returns range is the lowest compared to other observations. In mid-cap dividend announcement minimum, abnormal return is negative and highest among other observations. Small-cap dividend announcement during bear trend maximum return is positive and 
highest, and minimum return is negative and lowest compare to large and mid-cap dividend announcements. Small-cap dividend announcement abnormal returns range is high on event day.

Full sample dividend announcement abnormal returns maximum and minimum returns are equal to small-cap dividend announcement values. Mean of full sample, mid-cap, and small-cap dividend announcement is positive and less than one percent, but in large-cap, it is negative. Full sample, large-cap, mid-cap, and small-cap medians are negative and lesser than their means. The deviation of abnormal returns on event day in small-cap is highest, and in large-cap, it is lowest. It can be interpreted from the above table that small-cap abnormal returns are more in positive and large-cap abnormal returns more in the negative side on the event day.

Table 6. Event Day for final dividend announcements during bear market trend by market capitalization wise (Period 1: $3^{\text {rd }}$ Jan 08 to $3^{\text {rd }}$ Mar 09)

\begin{tabular}{clccccc}
\hline \multirow{2}{*}{ S. No } & \multirow{2}{*}{ Sample details } & \multicolumn{5}{c}{ Event day results } \\
\cline { 3 - 6 } & & AAR $(\%)$ & CAAR $(\%)$ & AAR t Stat & p Value & AAR Significance \\
\hline 4.1 .1 & Full sample & 0.187 & 2.743 & 0.736 & 0.462 & Not significant \\
4.1 .2 & Large-cap & -0.227 & 0.132 & -0.643 & 0.523 & Not significant \\
4.1 .3 & Mid-cap & 0.343 & 2.225 & 0.696 & 0.49 & Not significant \\
4.1 .4 & Small-cap & 0.333 & 4.397 & 0.799 & 0.426 & Not significant \\
\hline
\end{tabular}

Note. Author's calculations by using stock prices from bseindia.com.

* $5 \%$ level significance.

From the above Table 6, it can be said that full sample, mid-cap, and small-cap final dividend announcements during bear trend average abnormal returns are positive, and large-cap final dividend announcement average returns are in negative on the event day. Cumulative average abnormal returns also positive, but in large-cap, returns are close to zero percent. CAAR values are much higher values in small-cap than mid-cap and full sample announcements. Calculated $\mathrm{p}$ values are much higher than 0.05 value, so it means at a 5 percent level null hypothesis not rejected. It can be interpreted like that full sample, large-cap, mid-cap, and small-cap final dividend announcements during bear trend (period 1) not impact on the stock prices.

4.2 Bull Market Trend (Period 2: 4, March 2009 to 5, November 2010)

Table 7. Abnormal returns descriptive statistics of final dividend announcements by market capitalization wise during bull trend (period 2) on event day

\begin{tabular}{clcccccc}
\hline \multirow{2}{*}{ S. No } & \multirow{2}{*}{ Announcement type } & $\mathrm{N}$ & \multicolumn{5}{c}{ Descriptive statistics of abnormal returns (\%) } \\
\cline { 4 - 7 } & & & Max & Min & Mean & Median & SD \\
\hline 4.2 .1 & Full Sample & 320 & 19.431 & -9.392 & 0.764 & 0.237 & 4.42 \\
4.2 .2 & Large-cap & 97 & 13.781 & -5.812 & 0.733 & 0.139 & 3.621 \\
4.2 .3 & Mid-cap & 79 & 19.222 & -9.392 & -0.016 & 0.106 & 4.061 \\
4.2 .4 & Small-cap & 144 & 19.431 & -8.429 & 1.213 & 0.398 & 5.024 \\
\hline
\end{tabular}

Source: Author's calculations by using stock prices from bseindia.com.

It is found from above Table 7 that maximum positive abnormal return observed in small-cap final dividend announcement during a bull trend, and minimum negative abnormal return observed in mid-cap final dividend announcement on event day. In large-cap finds the lowest maximum return and highest minimum return, so large-cap announcement returns range is less compare to other observations. Full sample final dividend announcement range is high because it has the highest maximum return and lowest minimum return. Positive mean observes in full sample, large-cap, and small-cap, but in mid-cap observed slight negative mean and all observations medians are in positive. Full sample, large-cap and small-cap means are higher than respective their medians, but in mid-cap mean is slightly lesser than its median. Small-cap final dividend announcement abnormal returns deviation is highest and large-cap final dividend announcement deviation is low. It can interpret from the above discussion that maximum returns of mid-cap and small-cap same, but mean of small-cap is very high, it means that small-cap stocks abnormal returns are more positive and its volatility in abnormal return also high. 
Table 8. Event Day results for final dividend announcements during bull trend by market capitalization wise (Period 2: 4, March 2009 to 5, November 2010)

\begin{tabular}{clccccc}
\hline \multirow{2}{*}{ S. No } & \multirow{2}{*}{ Sample Details } & \multicolumn{5}{c}{ Event day results } \\
\cline { 3 - 7 } & & AAR $(\%)$ & CAAR $(\%)$ & AAR t Stat & p Value & AAR Significance \\
\hline 4.2 .1 & Full sample & $0.764^{*}$ & 5.528 & 3.092 & 0.002 & Significant \\
4.2 .2 & Large-cap & $0.733^{*}$ & 2.14 & 1.993 & 0.049 & Significant \\
4.2 .3 & Mid-cap & -0.016 & 5.113 & -0.036 & 0.971 & Not Significant \\
4.2 .4 & Small-cap & $1.213^{*}$ & 8.040 & 2.897 & 0.004 & Significant \\
\hline
\end{tabular}

Source: Author's calculations by using stock prices from bseindia.com.

* 5\% level significance.

It is observed from above Table 8 that average abnormal returns are positive in full sample, large-cap and small-cap final dividend announcements during bull market trend (period 2) and especially small-cap returns are very high, but mid-cap final dividend return is slightly in negative on the event day. An exciting thing observes from above table that cumulative average abnormal returns are positive and also very high on event day in all observations. Among all observations, small-cap CAAR returns on event day are very high, and large-cap returns are lowest. Calculated $\mathrm{p}$ values of full sample, large-cap and small-cap final dividend announcement during a bull trend are less than 0.05 , so it means that these observations abnormal returns on event day is significant but mid-cap final dividend returns are insignificant. It is interpreted from the above discussion that full sample, large-cap, and small-cap final dividend announcement during bull trend (period 2) impact is there on the stock price at 5 percent level significance.

\subsection{Bear Market Trend (Period 3: 6, November 2010 to 16, December 2011)}

Table 9. Abnormal returns descriptive statistics of final dividend announcements during bear trend (period 3) on event day

\begin{tabular}{|c|c|c|c|c|c|c|c|}
\hline \multirow{2}{*}{ S. No } & \multirow{2}{*}{ Sample details } & \multirow{2}{*}{$\mathrm{N}$} & \multicolumn{5}{|c|}{ Descriptive statistics of abnormal returns (\%) } \\
\hline & & & Max & Min & Mean & Median & SD \\
\hline 4.3 .1 & Full sample & 187 & 12.148 & -10.209 & -0.421 & -0.357 & 3.152 \\
\hline 4.3 .2 & Large-cap & 51 & 4.701 & -8.903 & -0.543 & -0.372 & 2.736 \\
\hline 4.3 .3 & Mid-cap & 47 & 9.265 & -6.532 & 0.120 & 0.434 & 2.939 \\
\hline 4.3.4 & Small-cap & 89 & 12.148 & -10.209 & -0.636 & -0.539 & 3.467 \\
\hline
\end{tabular}

Source: Author's calculations by using stock prices from bseindia.com.

Table 9 says that the highest positive maximum return observes in small-cap final dividend announcement during bear trend (period 3) and least minimum negative return notices in small-cap final dividend announcement abnormal returns on the event day. Small-cap abnormal returns range is high, and the large-cap returns range is less. Mean and median of full sample, large-cap, and small-cap abnormal returns on event day are negative, mainly small-cap mean is very low, but mid-cap mean and median are in positive. Interestingly median of all observations is high than their respective mean values. The deviation of abnormal returns in all the observations is almost the same; as usual, small-cap deviation little bit higher, and large-cap deviation is a little bit lower. It can be interpreted from the above discussion and table that bear market trend impact is evident on final dividend announcements abnormal returns on the event day. Bear trend impact is more on small-cap announcement and less on mid-cap announcements.

Table 10. Event day results for final dividend announcements during bear trend by market capitalization wise (Period 3: 6, November 2010 to 16, December 2011)

\begin{tabular}{llccccc}
\hline \multirow{2}{*}{ S. No } & \multirow{2}{*}{ Sample details } & \multicolumn{4}{c}{ Event day results } \\
\cline { 3 - 7 } & & AAR $(\%)$ & CAAR $(\%)$ & AAR t Stat & p Value & AAR Significance \\
\hline 4.3 .1 & Full sample & -0.421 & 1.217 & -1.824 & 0.069 & Not Significant \\
4.3 .2 & Large-cap & -0.543 & -0.912 & -1.417 & 0.163 & 0.781 \\
4.3 .3 & Mid-cap & 0.120 & 0.927 & 0.280 & Not Significant & Not Significant \\
4.3 .4 & Small-cap & -0.636 & 2.590 & -1.730 & 0.087 & Not Significant \\
\hline
\end{tabular}

Source: Author's calculations by using stock prices from bseindia.com.

$* 5 \%$ level significance. 
It can be understood from above Table 10 that during bear trend (period 3) full sample, large-cap, and small-cap final dividend announcements, average abnormal returns are negative on event day, but mid-cap returns are slightly positive. Interestingly cumulative average abnormal returns are positive on event day in full sample, mid-cap, and small-cap final dividend announcements, but values are less and large-cap returns are negative on the event day. Calculated $\mathrm{p}$ values of full sample, large-cap, mid-cap, and small-cap are higher than 0.05 , and it means that all observations abnormal returns are not significant. In can be interpreted from the above discussion that, bear market effecting on final dividend announcement abnormal returns negatively. Full sample, large-cap, mid-cap, and small-cap final dividend announcements during bear trend (period 3) not impact the stock price at a 5 percent level of significance. But full sample and small-cap average abnormal returns significant at 10 percent level significance.

4.4 Bull Market Trend (Period 4: 17, December 2011 to 5, March 2015)

Table 11. Abnormal returns descriptive statistics of final dividend announcements during bull trend (period 4) on event day

\begin{tabular}{clcccccc}
\hline \multirow{2}{*}{ S. No } & \multirow{2}{*}{ Announcement type } & \multirow{N}{*}{} & \multicolumn{5}{c}{ Descriptive statistics of abnormal returns (\%) } \\
\cline { 4 - 8 } & & & Max & Min & Mean & Median & SD \\
\hline 4.4 .1 & Full sample & 559 & 19.321 & -20.793 & 0.111 & -0.159 & 3.689 \\
4.4 .2 & Large-cap & 154 & 7.946 & -20.793 & -0.277 & -0.327 & 3.221 \\
4.4 .3 & Mid-cap & 131 & 13.377 & -7.712 & 0.071 & -0.226 & 3.240 \\
4.4 .4 & Small-cap & 274 & 19.321 & -16.275 & 0.349 & -0.051 & 4.105 \\
\hline
\end{tabular}

Source: Author's calculations by using stock prices from bseindia.com.

It is observed from above Table 11 that maximum positive abnormal return in small-cap final dividend announcement during bull trend (period 4) and minimum negative abnormal return in large-cap final dividend announcement in event day abnormal returns. In all observations least maximum abnormal return in large-cap and least minimum return is in mid-cap. The large-cap sample has the highest range of abnormal returns and the mid-cap sample has the least range. The mean of large-cap is in negative and remaining all in positive but mid-cap value is close to zero percent only. Full sample, large-cap, and mid-cap medians are in negative and small-cap median only in slightly negative. All observations median is lesser than their respective mean and most of the medians are close to respective means. Deviation of abnormal returns is above three in all observations and most of the announcement's deviations are equal to one other on the event day. As usual, small-cap stocks abnormal returns have the highest deviation, but instead of only large-cap here, both large and mid-cap have the least and equal deviation of abnormal returns.

Table 12. Event day results for final dividend announcements during bull trend by market capitalization wise (Period 4: 17, December 2011 to 5, March 2015)

\begin{tabular}{llccccc}
\hline & & \multicolumn{4}{c}{ Event day results } \\
\cline { 3 - 6 } S. No & Sample details & AAR $(\%)$ & CAAR $(\%)$ & $\begin{array}{c}\text { AAR } \\
\text { t Stat }\end{array}$ & p Value & AAR Significance \\
\hline 4.4 .1 & Full sample & 0.112 & 1.503 & 0.714 & 0.785 & Not significant \\
4.4 .2 & Large-cap & -0.277 & -0.251 & -1.067 & 0.288 & Not significant \\
4.4 .3 & Mid-cap & 0.071 & 0.158 & 0.251 & 0.819 & Not significant \\
4.4 .4 & Small-cap & 0.349 & 3.131 & 1.407 & 0.16 & Not significant \\
\hline
\end{tabular}

Source: Author's calculations by using stock prices from bseindia.com.

Note. ${ }^{*} 5 \%$ level significance.

From the above Table 12, it is observed that large-cap final dividend announcement during bull trend (period 4) has the least negative average abnormal returns among all observations and small-cap has the highest positive average abnormal return on the event day. Large-cap cumulative average abnormal return is negative on event day, but other observation returns are positive. Small-cap CAAR is highest among others; it supports that more number abnormal returns are positive before the event day. Calculated $\mathrm{p}$ values of full sample, large-cap, mid-cap, and small-cap final dividend announcement is above 0.05 , and so average abnormal returns of any observation are not significant at 5 percent level significance and null hypothesis not rejected. Interpretation of 
the above discussion is that full sample, large-cap, mid-cap, and small-cap final dividend announcement during bull trend (period 4) not impact the share price at a 5 percent level of significance

4.5 Bear Market Trend (period 5: 6, March 2015 to 12, February 2016)

Table 13. Abnormal returns descriptive statistics of final dividend announcement during bear trend (period 5) on event day

\begin{tabular}{clcccccc}
\hline \multirow{2}{*}{ S. No } & \multirow{2}{*}{ Sample details } & $\mathrm{N}$ & \multicolumn{5}{c}{ Descriptive statistics of abnormal returns (\%) } \\
\cline { 4 - 8 } & & & Max & Min & Mean & Median & SD \\
\hline 4.5 .1 & Full sample & 186 & 14.298 & -8.219 & 0.156 & -0.069 & 3.286 \\
4.5 .2 & Large-cap & 55 & 6.912 & -4.223 & 0.245 & 0.200 & 2.568 \\
4.5 .3 & Mid-cap & 45 & 13.947 & -6.858 & 0.184 & -0.066 & 3.288 \\
4.5 .4 & Small-cap & 86 & 14.298 & -8.219 & 0.084 & -0.318 & 3.703 \\
\hline
\end{tabular}

Source: Author's calculations by using stock prices from bseindia.com.

It can say from the above Table 13 that large-cap final dividend announcement during bear trend (period 5) maximum abnormal return is positive and lowest compared to mid-cap and small-cap maximum abnormal returns on the event day. Large-cap abnormal returns range is also the lowest compared to other observations. In mid-cap final dividend announcement maximum abnormal return is positive and slightly lesser than the small-cap maximum return. Small-cap final dividend announcement during bear trend maximum return is positive, and minimum return is negative and lowest compare to large and mid-cap final dividend announcements. Small-cap final dividend announcement samples' abnormal returns range is high on the event day.

Full sample final dividend announcement abnormal returns maximum is equal to small-cap maximum return, and minimum return also is equal to small-cap final dividend announcement value. Mean of full sample, large-cap, mid-cap, and small-cap final dividend announcement are positive, and especially small-cap mean is close to zero percent. Full sample, large-cap, mid-cap, and small-cap medians are slightly lesser than their means and only large-cap median is positive. The deviation of abnormal returns on event day in small-cap is highest and in large-cap, it is lowest. It can be interpreted from the above table that large-cap abnormal returns are more in positive and small-cap abnormal returns more in the negative side on the event day.

Table 14. Event day results final dividend announcements during bear trend by market capitalization wise (Period 5: 6, March 2015 to 12, February 2016)

\begin{tabular}{llccccc}
\hline & & \multicolumn{5}{c}{ Event day results } \\
\cline { 3 - 6 } S. No & Sample details & AAR & CAAR & AAR & $\mathrm{p}$ & AAR \\
& & $(\%)$ & $(\%)$ & t Stat & Value & Significance \\
\hline 4.5 .1 & Full sample & 0.156 & -0.133 & 0.647 & 0.518 & Not Significant \\
4.5 .2 & Large-cap & 0.245 & 0.039 & 0.708 & 0.482 & Not Significant \\
4.5 .3 & Mid-cap & 0.184 & -1.310 & 0.376 & 0.709 & Not Significant \\
4.5 .4 & Small-cap & 0.084 & 0.371 & 0.211 & 0.834 & Not Significant \\
\hline
\end{tabular}

Source: Author's calculations by using stock prices from bseindia.com.

Note. $* 5 \%$ level significance.

From the above Table 14, it can understand that full sample, large-cap, mid-cap, and small-cap final dividend announcements during bear trend average abnormal returns are positive. Cumulative average abnormal returns are positive in small-cap final dividend announcement only, but in other final dividend announcements, cumulative returns are in negative or closer to zero. CAAR values in full sample and large-cap announcement close to zero, but in mid-cap, it is negatively higher than one percent and in a small-cap positively little bit higher than zero percent. Calculated $\mathrm{p}$ values are much higher than 0.05 value, so it means at a 5 percent level null hypothesis not rejected. It can be interpreted that full sample, large-cap, mid-cap, and small-cap final dividend announcement during bear trend (period 5) not impact the stock prices. 
4.6 Bull Market Trend (period 6: 13, February 2016 to 01, January 2018)

Table 15. Abnormal returns descriptive statistics of final dividend announcements during bull trend (period 6) on event day

\begin{tabular}{clcccccc}
\hline \multirow{2}{*}{ S. No } & \multirow{2}{*}{ Sample details } & $\mathrm{N}$ & \multicolumn{4}{c}{ Descriptive statistics of abnormal returns (\%) } \\
\cline { 4 - 7 } & & & Max & Min & Mean & Median & SD \\
\hline 4.6 .1 & Full sample & 298 & 13.947 & -10.793 & 0.274 & 0.126 & 3.318 \\
4.6 .2 & Large-cap & 81 & 11.495 & -9.230 & 0.002 & -0.244 & 3.015 \\
4.6 .3 & Mid-cap & 73 & 13.947 & -4.510 & 0.724 & 0.180 & 3.305 \\
4.6 .4 & Small-cap & 144 & 11.284 & -10.793 & 0.199 & 0.411 & 3.482 \\
\hline
\end{tabular}

Source: Author's calculations by using stock prices from bseindia.com.

Table 15 says that mid-cap final dividend announcement during bull trend (period 6) maximum abnormal return is positive and slightly highest compare to large-cap and small-cap maximum abnormal return on event day. Small-cap abnormal returns range is highest compare to other observations. In small-cap final dividend announcement maximum abnormal return is positive and lowest among other observations. Mid-cap final dividend announcement during bull trend minimum return is negative and highest compare to large and small-cap final dividend announcements. Full sample final dividend announcement abnormal returns maximum is equal to mid-cap maximum return, and minimum return is equal to small-cap final dividend announcement value.

The mean of full sample, large-cap, mid-cap, and small-cap final dividend announcements is positive and less than one percent. Full sample, large-cap, and mid-cap medians are slightly lesser than their means and the only large-cap median is in negative, but the small median is a little bit higher than its mean. Deviation of abnormal returns on event day is almost equal in all observations and in small-cap, it is highest and in large-cap, it is lowest, but deviations are close to each other. It can be interpreted from the above table that mid-cap abnormal returns are more in positive and large-cap abnormal returns more in the negative side on the event day.

Table 16. Event day results for final dividend announcements during bull trend by market capitalization wise (Period 6: 13, February 2016 to 01, January 2018)

\begin{tabular}{llccccc}
\hline & & \multicolumn{4}{c}{ Event day results } \\
\cline { 3 - 6 } S. No & Sample details & AAR $(\%)$ & CAAR $(\%)$ & $\begin{array}{c}\text { AAR } \\
\text { t Stat }\end{array}$ & p Value & AAR Significance \\
\hline 4.6 .1 & Full sample & 0.274 & -0.245 & 1.425 & 0.155 & Not Significant \\
4.6 .2 & Large-cap & 0.002 & -0.406 & 0.006 & 0.994 & Not Significant \\
4.6 .3 & Mid-cap & 0.723 & -0.626 & 1.871 & 0.065 & Not Significant \\
4.6 .4 & Small-cap & 0.198 & 0.039 & 0.685 & 0.494 & Not Significant \\
\hline
\end{tabular}

Source: Author's calculations by using stock prices from bseindia.com.

Note. ${ }^{*} 5 \%$ level significance.

From the above Table 16, it can understand that full sample, large-cap, mid-cap, and small-cap final dividend announcements during bull trend average abnormal returns are in positive, but large-cap final dividend announcement average return is almost close to zero percent on event day. Cumulative average abnormal returns are slightly positive in small-cap final dividend announcements, but in other final dividend announcements, full sample, large and mid-cap returns are in negative. Calculated $\mathrm{p}$ values of full sample, large-cap, mid-cap, and small-cap are much higher than 0.05 value, so it means at 5 percent level null hypothesis not rejected. It can be interpreted that full sample, large-cap, mid-cap, and small-cap final dividend announcement during bull trend (period 6) not impact the stock prices.

\subsection{Consolidation Results of Market Trends by Market Capitalization Wise \\ a. Full sample Firms}


Table 17. Event day results full sample final dividend announcements during different market trends

\begin{tabular}{|c|c|c|c|c|c|c|c|}
\hline \multirow[b]{2}{*}{ S. No } & \multirow[b]{2}{*}{ Market Trend } & \multirow[b]{2}{*}{$\mathrm{N}$} & \multicolumn{5}{|c|}{ Event day results } \\
\hline & & & $\operatorname{AAR}(\%)$ & CAAR $(\%)$ & $\begin{array}{l}\text { AAR } \\
\text { t Stat }\end{array}$ & $\mathrm{p}$ Value & AAR Significance \\
\hline 4.1 .1 & Bear market trend (P 1) & 205 & 0.188 & 2.744 & 0.737 & 0.462 & Not Significant \\
\hline 4.2 .1 & Bull market trend (P 2) & 320 & $0.764 *$ & 5.529 & 3.092 & 0.002 & Significant \\
\hline 4.3 .1 & Bear market trend (P 3) & 187 & -0.421 & 1.217 & -1.825 & 0.07 & Not Significant \\
\hline 4.4 .1 & Bull market trend (P 4) & 559 & 0.111 & 1.503 & 0.714 & 0.785 & Not Significant \\
\hline 4.5 .1 & Bear market trend (P 5) & 186 & 0.156 & -0.134 & 0.647 & 0.518 & Not Significant \\
\hline 4.6 .1 & Bull market trend (P 6) & 298 & 0.274 & -0.245 & 1.425 & 0.155 & Not Significant \\
\hline
\end{tabular}

Source: Author's calculations by using stock prices from bseindia.com.

Note. $* 5 \%$ level significance.

In full sample final dividend announcements, average abnormal returns (AAR) are positive in most of the market trends, but values are less than one percent on the event day. It is observed the highest value in bull trend (period 2 ) and the lowest value in bear trend (period 3). Cumulative average abnormal returns also positive in most of the trends except periods $5 \& 6$ and higher positive notices during bull trend (period 2), but remaining in other period values are low and also a little bit higher than one percent. Calculated p values are less than 0.05 in a bull market (period 2) only; it means null hypothesis rejects for this period only, and remaining in other periods values are higher than 0.05 . So, it can be interpreted that full sample final dividend announcements during bull market (period 2) impact on stock prices and remaining in other periods no impact on stock prices at 5 percent significance level. But full sample average abnormal returns significant at 10 percent level significance during bear trend (period 2).

\section{b. Large-cap Firms}

Table 18. Event day results for large-cap final dividend announcements during different market trends.

\begin{tabular}{|c|c|c|c|c|c|c|c|}
\hline \multirow[b]{2}{*}{ S. No } & \multirow[b]{2}{*}{ Market trend } & \multirow[b]{2}{*}{$\mathrm{N}$} & \multicolumn{5}{|c|}{ Event day results } \\
\hline & & & $\operatorname{AAR}(\%)$ & $\begin{array}{c}\text { CAAR } \\
(\%)\end{array}$ & $\begin{array}{l}\text { AAR } \\
\text { t Stat }\end{array}$ & $\mathrm{p}$ Value & $\begin{array}{c}\text { AAR } \\
\text { Significance }\end{array}$ \\
\hline 4.1 .2 & Bear market trend (P 1) & 54 & -0.227 & 0.132 & -0.643 & 0.523 & Not Significant \\
\hline 4.2 .2 & Bull market trend (P 2) & 97 & $0.733^{*}$ & 2.14 & 1.993 & 0.049 & Significant \\
\hline 4.3 .2 & Bear market trend (P 3) & 51 & -0.543 & -0.912 & -1.417 & 0.163 & Not Significant \\
\hline 4.4 .2 & Bull market trend (P 4) & 154 & -0.277 & -0.251 & -1.067 & 0.288 & Not Significant \\
\hline 4.5 .2 & Bear market trend (P 5) & 55 & 0.245 & 0.039 & 0.708 & 0.482 & Not Significant \\
\hline 4.6 .2 & Bull market trend (P 6) & 81 & 0.002 & -0.407 & 0.006 & 0.995 & Not Significant \\
\hline
\end{tabular}

Source: Author's calculations by using stock prices from bseindia.com.

Note. $* 5 \%$ level significance.

In large-cap final dividend announcements, average abnormal returns are either negative or closer to zero percent in most of the periods on event day. It is observed the highest value in bull trend (period 2) and lowest in bear trend (period 3). Cumulative average abnormal returns are also negative in most of the periods and it is highest in bull trend (period 2) and lowest in bear trend (period 3). Calculated p values are less than 0.05 in a bull market (period 2) only; it means null hypothesis rejects for this period, and remaining in other periods values are higher than 0.05. So, it can be interpreted that large-cap final dividend announcements during bull market (period 2) impact on stock prices and remaining in other periods no impact on stock prices at a 5 percent significance level.

c. Medium Cap Firms 
Table 19. Event day results for mid-cap final dividend announcements during different market trends.

\begin{tabular}{cccccccc}
\hline & & & \multicolumn{3}{c}{ Event day results } \\
\cline { 5 - 8 } S. No & Market trends & $\mathrm{N}$ & AAR $(\%)$ & $\begin{array}{c}\text { CAAR } \\
(\%)\end{array}$ & $\begin{array}{c}\text { AAR } \\
\mathrm{t} \text { Stat }\end{array}$ & $\mathrm{p}$ Value & AAR Significance \\
\hline 4.1 .3 & Bear market trend (P 1) & 50 & 0.343 & 2.225 & 0.696 & 0.490 & Not Significant \\
4.2 .3 & Bull market trend (P 2) & 79 & -0.016 & 5.113 & -0.036 & 0.971 & Not Significant \\
4.3 .3 & Bear market trend (P 3) & 47 & 0.120 & 0.927 & 0.280 & 0.781 & Not Significant \\
4.4 .3 & Bull market trend (P 4) & 131 & 0.071 & 0.158 & 0.251 & 0.819 & Not Significant \\
4.5 .3 & Bear market trend (P 5) & 45 & 0.184 & -1.310 & 0.376 & 0.709 & Not Significant \\
4.6 .3 & Bull market trend (P 6) & 73 & 0.724 & -0.627 & 1.870 & 0.065 & Not Significant \\
\hline
\end{tabular}

Source: Author's calculations by using stock prices from bseindia.com.

Note. * $5 \%$ level significance.

Surprising results observed in mid-cap final dividend announcement during different market trends, that is except bull trend (period 2) in other periods, average abnormal returns are in positive. Actually, during bull trend (period 2), abnormal returns are positive on event day in other caps final dividend announcements. It is noticed that another essential thing is that the highest value in bull trend (period 6) and lowest in bull trend (period 2). Cumulative average abnormal returns are positive in the first four period's market trends and negative in the last two periods. Calculated $\mathrm{p}$ values are not less than 0.05 in any trend or period. So it can be interpreted that mid-cap final dividend announcements during any market trend no impact on stock prices at a 5 percent significance level.

d. Small-cap Firms

Table 20. Event day results for small-cap final dividend announcements during different market trends.

\begin{tabular}{|c|c|c|c|c|c|c|c|}
\hline \multirow[b]{2}{*}{ S. No } & \multirow[b]{2}{*}{ Market trends } & \multirow[b]{2}{*}{$\mathrm{N}$} & \multicolumn{5}{|c|}{ Event day results } \\
\hline & & & $\operatorname{AAR}(\%)$ & CAAR $(\%)$ & $\begin{array}{l}\text { AAR } \\
\text { t Stat }\end{array}$ & $\mathrm{p}$ Value & AAR Significance \\
\hline 4.1 .4 & Bear market trend (P 1) & 101 & 0.333 & 4.397 & 0.799 & 0.426 & Not Significant \\
\hline 4.2 .4 & Bull market trend (P 2) & 144 & $1.213^{*}$ & 8.04 & 2.897 & 0.004 & Significant \\
\hline 4.3 .4 & Bear market trend (P 3) & 89 & -0.636 & 2.59 & -1.73 & 0.087 & Not Significant \\
\hline 4.4 .4 & Bull market trend (P 4) & 274 & 0.349 & 3.131 & 1.407 & 0.16 & Not Significant \\
\hline 4.5 .4 & Bear market trend (P 5) & 86 & 0.084 & 0.371 & 0.211 & 0.834 & Not Significant \\
\hline 4.6 .4 & Bull market trend (P 6) & 144 & 0.199 & 0.039 & 0.685 & 0.494 & Not Significant \\
\hline
\end{tabular}

Source: Author's calculations by using stock prices from bseindia.com.

Note. * $5 \%$ level significance.

In the small-cap final dividend announcements, average abnormal returns (AAR) are positive in all three bull periods (periods 2, 4 \& 6) and two bear periods (Period $1 \& 5$ ) but negative in one bear period (period 3) on the event day. It is observed the very high value in bull trend (period 2) and very low value in bear trend (period 3 ). Cumulative average abnormal returns positive in all periods and higher positive notices in during bull trend (period 2) and lowest positive value observes in bear trend (period 6). Calculated p values are less than 0.05 in a bull market (period 2) only; it means null hypothesis rejects for this one period, and remaining in other periods values are higher than 0.05 . So, it can be interpreted that small-cap final dividend announcement during a bull market (period 2) impact the stock prices and remaining in other periods no impact on stock prices at a 5 percent significance level. But small-cap average abnormal returns significant at 10 percent level significance in bear market trend (period 3).

It can be understood from the above discussion that average abnormal returns are reacting to the market trends in most of the announcements by market capitalization wise, especially small-cap companies are reacting more favourable to the market trends in most of the periods but mid-cap companies little opposite to this. An important observation is that in some cases, if market returns high stocks abnormal returns also high, for example, during bull trend S\&P BSE 500 change is 172.73 percent, and during this period, most abnormal returns are positive and returns statistically significant also. 


\section{Conclusion}

The present research study examined the impact of dividend announcements on stocks in the Indian stock market. The results observe in twenty-four times based on market capitalization wise and market trend-wise in final dividend announcements. The results of the study are not the same for all dividend announcement observations. The study found positive abnormal returns on event day in most of the dividend announcement observations and it is similar to Litzenberger and Ramaswamy (1982), Asquith and Mullins Jr (1983), Grinblatt, Masulis, and Titman (1984), Chen, Nieh, Da Chen, and Tang (2009) and many previous research results studied in major developed stock markets and emerging stock markets.

Full sample, large-cap, and small-cap final dividend average abnormal returns are positively significant only in bull market trend (period 2) similar to Below and Johnson (1996) and other market trends final dividend announcement abnormal returns are positive in most of the observations, but returns are not significant. Average abnormal returns are sensitive to market trends, especially abnormal small-cap returns more vulnerable to market trends. So, different market capitalization final dividend announcements impact on stocks in India varies in different market trends. Full sample and small-cap final dividend announcement abnormal returns are positively significant during bull market trend (period 2), so it concludes that returns in this observation might be influenced the full sample and small-cap final dividend announcement abnormal returns.

Hence, it is concluded from the above discussion that dividend announcement observations generate positive abnormal returns, but returns are not significant in most of the observations. It is also concluded that dividend announcement impact varies with market capitalization wise, in market trends. Further, small-cap returns are different and their standard deviations also high compared to other cap announcement returns and also this study supports the anomaly of the size effect. This study also concludes that a semi-strong form of efficient hold for some observations only not for all observations.

\section{References}

Amihud, Y., \& Li, K. (2006). The Declining Information Content of Dividend Announcements and the effects of Institutional Holdings. Journal of Financial and Quantitative Analysis, 41(3), 637-660. https://doi.org/10.1017/s0022109000002568

Asquith, P., \& Mullins, D. (1983). The Impact of Initiating Dividend Payments on Shareholders' Wealth. The Journal of Business, 56(1), 77-96. https://doi.org/10.1086/296187

Balu, B. M., Fuller, K. P., \& Van Ness, R. A. (2011). Short Selling around Dividend Announcements and Ex-dividend Days. Journal of Corporate Finance, 17(3), 628-639. https://doi.org/10.1016/j.jcorpfin.2010.11.001.

Below, S., \& Johnson, K. (1996). An analysis of shareholder reannouncement to dividend announcements in bull and bear markets. Journal of Financial and Strategic Decisions, 9(3), 15-26. Retrieved from https://studyfinance.com/jfsd/pdffiles/v9n3/below.pdf.

Berdnikova, G., \& Rogova, E. (2013). The analysis of market reannouncement on dividend announcements of Russian companies. GSOM emerging Markets Conference: Business and Government Perspectives. Retrieved from https://ssrn.com/abstract=2511873.

Bessembinder, H., \& Zhang, F. (2015). Predictable corporate distributions and stock returns. Review of Financial Studies, 28(4), 1199-1241. https://doi.org/10.1093/rfs/hhu145

Bessler, W., \& Nohel, T. (2000). Asymmetric Information, Dividend Reductions, and Contagion Effects in Bank Stock Returns. Journal of Banking and Finance, 24(11), 1831-1848. https://doi.org/10.1016/S0378-4266(99)00097-7

Brown, S. J., \& Warner, J. B. (1980). Measuring Security Price Performance. Journal of Financial Economics, 8(3), 205-258. https://doi.org/10.1016/0304-405X(80)90002-1

Chavali, K., \& Nusratunnisa. (2013). Impact of Dividends on Share Price Performance of Companies in Indian Context. SDMIMD Journal of Management, 4(1), 4-9. https://doi.org/10.18311/sdmimd/2013/2681

Chen, D. H., Liu, H. H., \& Huang, C. T. (2009). The Announcement Effect of Cash Dividend Changes on Share Prices: An Empirical Analysis of China. Chinese Economy, 42(1), 62-85. https://doi.org/10.2753/CES1097-1475420103

Corrado, C. J. (2011). Event studies: A methodology review. Accounting and Finance, 51(1), 207-234. https://doi.org/10.1111/j.1467-629X.2010.00375.x 
Dasilas, A., \& Leventis, S. (2011). Stock Market Reannouncement to Dividend Announcements: Evidence from Greek Stock Market. International Review of Economics and Finance, 20(2), 302-311. https://doi.org/10.1016/j.iref.2010.06.003

Del Brio, E. (2004). Insider Trading Around Dividend Announcements: The Spanish Evidence. https://doi.org/10.2139/ssrn.492602

DissaBandara, P. H., \& Samarakoon, L. P. (2002). Dividend Announcements, Firm Size and Dividend in the Sri Lankan Stock Market.pdf. Sri Lanka Journal of Management, 7(2), 228-245.

Elfakhani, S. (1998). The Expected Favourableness of Dividend Signals, the Direction of Dividend Change and the Signalling Role of Dividend Announcements. Applied Financial Economics, 8(3), 221-230. https://doi.org/10.1080/096031098332989

Fama, E. F., \& French, K. R. (2000). Disappearing Dividends: Changing Firm Characteristics or Lower Propensity to Pay? AFA 2001 New Orleans; CRSP Working Paper No. 509. https://doi.org/10.2139/ssrn.203092

Fama, E., Fisher, L., Jensen, M., \& Roll, R. (1969). The Adjustment of Stock Prices to New Information. International Economic Review, 10(1), 1-21. https://doi.org/ 10.2307/2525569.

Foster, T., \& Vickrey, D. (1978). The information content of stock dividend announcements. The Accounting Review, 53(2), 360-370.

Gunalp, B., Kadioglu, E., \& Killc, S. (2011). The Announcement Effect of Cash Dividend on Share Prices and the Tax Clientele Effect: Evidence from Turkish Capital Markets. Euro Conference 2011: Crises and Recovery in Emerging Markets. https://doi.org/10.13140/RG.2.1.2980.4400

Gupta, S., Dogra, B., Vashisht, A. K., \& Ghai, S. (2012). Stock Price Reannouncements to Dividend Announcements. International Journal of Management, 2(2), 23-31

Hussainey, K., Chijoke, O., \& Chijokemgbame, M. (2011). Dividend policy and share price volatility: UK evidence Dividend Policy and Share Price Volatility: UK Evidence. Journal of Risk Finance, 12(1), 57-68. https://doi.org/10.1108/15265941111100076.

John, K., \& Larry, H. P. L. (1991). Insider Trading around Dividend Announcements: Theory and Evidence. The Journal of Finance, 46(4), 1361-1389. https://doi.org/10.2307/2328862

Kalay, A. (1982). The Ex-Dividend Day Behaviour of Stock Prices: A Re-Examination of the Clientele Effect. The Journal of Finance, 37(4), 1059-1070. https://doi.org/10.2307/2327767

Kempf, E., Manconi, A., \& Spalt, O. (2017). Distracted Shareholders and Corporate Announcements. Review of Financial Studies, 30(5), 1660-1695. https://doi.org/10.1093/rfs/hhw082

Kothari, S. P., \& Warner, J. B. (2007). Econometrics of Event Studies. Handbook of Empirical Corporate Finance SET, 2, 3-36. https://doi.org/10.1016/B978-0-444-53265-7.50015-9.

Litzenberger, R., \& Ramaswamy, K. (1982). The Effects of Dividends on Common Stock Prices Tax Effects or Information Effects? The Journal of Finance, 37(2), 429-443. https://doi.org/10.2307/2327346

Marisetty, N., \& Babu, S. (2017). Corporate (Dividend) Announcements and Impact on Stock Abnormal Returns: A Study on Indian Context. International Journal of Management and Social Sciences Research, 6(11), 30-35.

Marisetty, N., \& Babu, S. (2018). Impact of Corporate Announcement (Different Stock Split Ratios) on Stock Price in India. International Journal of Research in Economics and Social Sciences, 8(1), 205-213.

Marisetty, N. (2018). A Study on the Impact of Dividend Announcements on Stock Prices in Indian Capital Market. ttps://doi.org/10.2139/ssrn.3145038

Marisetty, N., \& Madasu, P. (2021). Corporate Announcements and Market Efficiency: A Case on Indian Capital Market. International Journal of Business and Management, 16(8), 71. https://doi.org/10.5539/ijbm.v16n8p71

Marisetty, N., \& Madasu, P. (2021). Signaling Hypothesis and Size Anomaly in Indian Stock Market. International Business Research, 14(9), 94. https://doi.org/10.5539/ibr.v14n9p94

Michaely, R., Rubin, A., \& Vedrashko, A. (2016). Are Friday announcements special? Overcoming selection bias. Journal of Financial Economics, 122(1), 65-85. https://doi.org/10.1016/j.jfineco.2016.05.006 
Mishra, D., Racine, M. D., \& Schmidt, L. (2011). Credibility of corporate announcements and market reannouncement: Evidence from Canadian share repurchase programs. Canadian Journal of Administrative Sciences, 28(1), 83-100. https://doi.org/10.1002/cjas.127

Ngoc, D. B., \& Cuong, N. C. (2016). Dividend Announcement and Ex-dividend Announcement Effects on Stocks Returns. International Journal of Economics and Finance, 8(7), 207-215. https://doi.org/10.5539/ijef.v8n7p207

Schwert, G. W. W. (2005). Anomalies and Market Efficiency. SSRN Electronic Journal. https://doi.org/10.2139/ssrn.338080

Vieira, E., \& Raposo, C. (2007). Signalling with Dividends? The Signalling Effects of Dividend Change Announcements: New Evidence from Europe. https://doi.org/10.2139/ssrn.955768

\section{Copyrights}

Copyright for this article is retained by the author(s), with first publication rights granted to the journal.

This is an open-access article distributed under the terms and conditions of the Creative Commons Attribution license (http://creativecommons.org/licenses/by/4.0/). 